\title{
悪性骨腫瘍に対する患肢温存療法の機能と予後
}

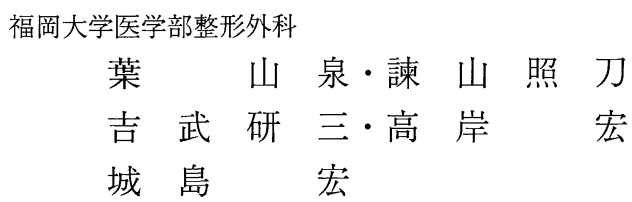

\section{Results of Limb Salvage for Malignant Bone Tumors}

by

Sansen Yoh, Teruto Isayama, Kenzo Yoshitake, Hiroshi Takagishi and Hiroshi Jojima

Department of Orthopaedic Surgery,

School of Medicine, Fukuoka University

\begin{abstract}
Nineteen patients with malignant bone tumors treated by limbsalvage procedures were evaluated. Histological diagnoses were chondrosarcoma (6), osteosarcoma (6), malignant fibrous histiocytoma (2), Ewing's sarcoma (2) and giant cell tumor (3). The surgical stages were: Stage I B (6), Stage II A (2), Stage II B (9) and Stage III (2). Fourteen patients were treated by preoperative and/or postoperative intra-arterial chemotherapy. The operative procedures were tumor resection alone (5) and reconstruction with bone graft (3), bone cement (2), prosthetic humeral head (1), total shoulder arthroplasty (2) and total knee arthroplasty (5). One patient required no surgery, following complete response with intra-arterial high-dose adriamycin.

The most common complication of patients with marginal (5) or intra-lesional surgical margin (2) was local recurrence (36\%).

Functional evaluations were excellent (7), good (10), fair (2) and poor (3). Metastasis was $47 \%$, death $42 \%$ and disease free survival $58 \%$ with a mean follow-up of 55 months. Careful preoperative selection and attention to limb salvage procedures are important for a successful outcome.
\end{abstract}

\section{はじめに}

近年の画像診断法，化学療法および手術療法の発達 により悪性骨腫瘍に対する患肢温存療法が比較的容易 に行われるようになってきた．今後の治療の参考とす るため，当科で行った原発性悪性骨腫瘍に対する患肢 温存療法の機能と予後を検索したので報告する. また，広範切除術を必要とした骨巨細胞腫もあわせて 報告する。

\section{症例および方法}

対象症例は患肢温存療法を行った原発性悪性骨腫瘍 は 16 例㧍よび広範切除を必要とした骨巨細胞腫は 3
例の計 19 例. 性別は男 12 例，女 7 例，年令は 10 才 加 68 才, 平均 33 才. 観察期間は 9 力月から 11 年 2 力月, 平均 4 年 7 力月. 発生部位は上肢は上腕骨 4 例，肩甲骨 2 例，橈骨，尺骨各 1 例の計 8 例，下肢は 大腿骨 6 例，脛骨 3 例，腸骨 2 例の計 11 例で，大腿 骨が多かった。

組織診断は軟骨肉腫, 骨肉腫各 6 例, 巨細胞腫 3 例, Ewing 肉腫, $\mathrm{MFH}$ 各 2 例で, 軟骨肉腫と骨肉腫が 多かった. Surgical Stage (Enneking) は I B 6 例， II A 2 例， II B 9 例， III 2 例と比較的進行例 が 多かった (表 1).

初回手術として再建術が行われたのは動注化学療法 が奏効して手術不要なった 1 例 ${ }^{3)}$ と広範切除のみの 5 
表 1 組織診断と Surgical Stage

\begin{tabular}{c|c|c|c|c|c|c}
\hline \hline Surgical Stage & 軟骨肉腫 & 骨 肉 腫 & Ewing 肉腫 & MFH & 巨細胞腫 & 計 \\
\hline I B & 3 & & & & 3 & 6 \\
II A & & 1 & & 1 & & 2 \\
II B & 3 & 3 & 2 & 1 & & 9 \\
III & & 2 & & & & 2 \\
\hline 計 & 6 & 6 & 2 & 2 & 3 & 19 \\
\hline
\end{tabular}

表 2 治療法

\begin{tabular}{|c|c|c|c|c|c|c|}
\hline 初回手術 & 軟骨肉腫 & 骨 肉 腫 & Ewing 肉腫 & $\mathrm{MFH}$ & 巨細胞腫 & 計 \\
\hline 手術不要 & & & 1 & & & 1 \\
\hline 広範切除のみ & $2+1^{*}$ & $1^{*}$ & 1 & & & 5 \\
\hline 骨，移 植 & 2 & $1^{*}$ & & & & 3 \\
\hline 骨セメント充填 & & & & $1^{* *}$ & $1^{* *}$ & 2 \\
\hline 近位上腕骨 & & & & & 1 & 1 \\
\hline 人工肩関節 & 1 & 1 & & & & 2 \\
\hline 人工膝関節 & & 3 & & 1 & 1 & 5 \\
\hline 計 & 6 & 6 & 2 & 2 & 3 & 19 \\
\hline
\end{tabular}

\begin{tabular}{|l|l|l|l|l|l|l}
\hline 動注化学療法 & 2 & 6 & 2 & 2 & 2 & 14 \\
\hline
\end{tabular}

例を除く 14 例で，切除後に骨移植 ・骨セメント充填 のほか近位上腕骨・人工肩関節・人工膝関節置換術 ${ }^{2)}$ などが必要であった。なお，術前および・または術後 の動注化学療法を 14 例に併用した（表 2).

\section{結果}

初回治療後の合併症として, 局所再発 7 例, 人工䩔 帯断裂 2 例，偽関節，人工関節七ラミックステム折損， 人工関節置換後遅発感染各 1 例がみられた。したがっ て, 追加手術として骨移植術 3 例, 追加広範切除術の み 2 例, 人工全大腿骨 - 人工滕関節 - 人工䩲带再置換 による再建術各 1 例のほか， 2 例には切断術が必要で あった。なお，人工関節感染例には rotation plasty をおこない鎮静化した ${ }^{6)}$. 最終的な術後の患肢機能評 価 (Enneking) は scapulectomy や比較的切除範 囲の少なかったTikhoff-Linberg procedure（図 1) を含め 14 例が Good 以上と比較的良好であった。 しかし, 切除範囲が広範な Tikhoff-Linberg procedure, 脛骨の人工鞖帯断裂例が Fair と不良で, 局所 再発の 3 例のうち 2 例は切離断術を施行, 1 例は上腕
骨近位 multi-centric osteosarcoma であったこと もあり再手術を承諾せず腕神経麻痺をきたし Poor と 悪かった1) (表 3 ).

予後をみると，局所再発が 7 例 $(36 \%)$ にみられ た.これらは全て切除縁に問題があり，4例は一部に marginal marginがみられ，3例は術前診断が良 性であった為に病巣掻爬術を行ったもの（intralesional）である。遠隔転移が 9 例 (47\%) にみられ， うち巨細胞腫の 1 例を除く 8 例 $(42 \%)$ が死亡し，無 病生存は11例（58\%）のみと悪かった（表 4 ）。腸骨 軟骨肉腫 2 例と動注化学療法が奏効しなかった肩甲骨 Ewing 肉腫の 1 例が局所再発と遠隔転を認め死亡し た。とくに，骨肉腫では 6 例中 5 例 $(83 \%)$ が遠隔転 移のため死亡した（1 例は局所再発有）。骨肉腫の初 回手術として患肢温存が行われた 6 例中 2 例が再発し， 5 例 $(83 \%)$ が転移で死亡しているのに比べ，切離断 術を行った 6 例は局所再発はなく，2 例 $(33 \%)$ のみ が肺転移で死亡，4例 (67\%) が無病生存中である. このことは切離断例が全て convetional osteosarcoma であったのに比べ，患肢温存例は stage III の 


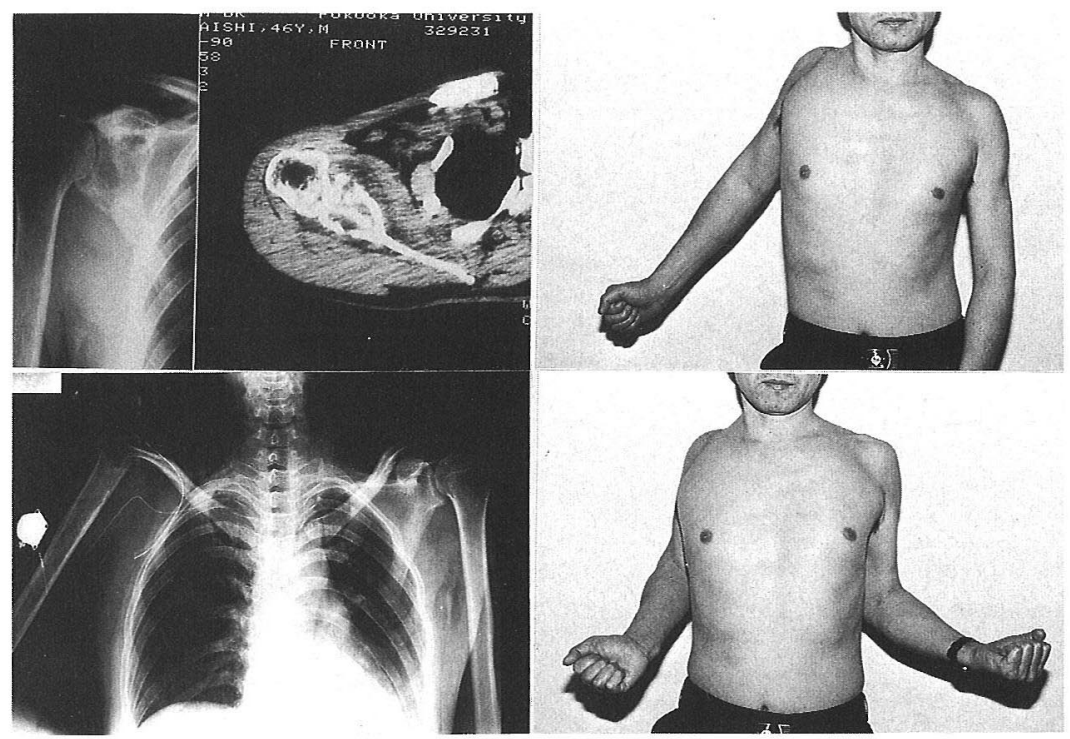

图 1 局甲骨軟骨肉腫

Tikhoff-Linberg procedure, 上腕三頭筋屒頭と菱形筋の切離端を

縫着しているので自動外旋が可能

表 3 患肢機能評価

\begin{tabular}{|c|c|c|c|c|c|c|}
\hline 患肢機能 & 軟骨肉腫 & 骨肉腫 & Ewing 肉腫 & $\mathrm{MFH}$ & 巨細胞腫 & 計 \\
\hline Excellent & 3 & & 1 & & & 4 \\
\hline Good & 2 & 3 & 1 & 2 & 2 & 10 \\
\hline Fair & & 1 & & & 1 & 2 \\
\hline Poor & $1 *$ & $2^{*}$ & & & & \\
\hline 計 & 6 & 6 & 2 & 2 & 3 & 19 \\
\hline
\end{tabular}

表 4 予 後

\begin{tabular}{|c|c|c|c|c|c|c|}
\hline 予 & $\begin{array}{c}\text { 軟骨肉腫 } \\
6\end{array}$ & $\begin{array}{c}\text { 骨肉腫 } \\
6\end{array}$ & \begin{tabular}{|c|} 
Ewing 肉腫 \\
2
\end{tabular} & $\begin{array}{l}\mathrm{MFH} \\
2\end{array}$ & $\begin{array}{c}\text { 巨細胞腫 } \\
3\end{array}$ & $\begin{array}{l}\text { 計 } \\
19 \\
\end{array}$ \\
\hline 局所再発 & $2^{*}$ & $1^{*}+1^{* *}$ & $1^{*}$ & $1^{* *}$ & 1 * & 7 \\
\hline 遠隔転移 & 2 & 5 & 1 & & 1 & 9 \\
\hline 無病生存 & 4 & 1 & 1 & 2 & 3 & 11 \\
\hline 死 & 2 & 5 & 1 & & & 8 \\
\hline
\end{tabular}

進行例, multicentric osteosarcoma, 50 才以上の 高齢発症非定型例が各々 2 例（1 例は stage III multi-centric osteosarcoma）と6 例中 5 例が予後 不良例であったことにも起因すると思われた（表 5 ）。
考察およびまとめ

墨性骨腫瘍の機能と予後を決定する大きな因子とし て切除範囲 (surgical margin) がある. 動注化学

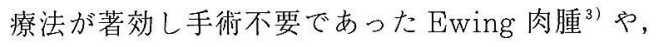


表 5 骨肉腫の予後

骨肉腫の予後

\begin{tabular}{c|c|c|c}
\hline \hline 初回手術 & 患肢温存 & 切 離 断 & 計 \\
\hline II A & 1 & & 1 \\
II B & 3 & 6 & 9 \\
III & 2 & & 2 \\
\hline 局所再発 & 2 & 0 & 2 \\
遠隔転移 & 5 & 2 & 7 \\
\hline 無病生存 & 1 & 4 & 5 \\
死 亡 & 5 & 5 & 7 \\
\hline
\end{tabular}

非定型例，Stage III を除く

\begin{tabular}{c|c|c|c}
\hline \hline 初回手術 & $\begin{array}{c}\text { 患肢温存 } \\
\text { 切 離 }\end{array}$ & $\begin{array}{c}\text { 䉼 } \\
7\end{array}$ \\
\hline 局所再発 & 0 & 0 & 2 \\
遠隔転移 & 1 & 2 & 6 \\
\hline 無病生存 & 1 & 4 & 5 \\
死 亡 & 0 & 2 & 2 \\
\hline
\end{tabular}

low gradeの軟骨肉腫のように切除範囲が少なけれ ば当然のことながら患肢機能は良好である。しかし， high grade 骨腫瘍に扔いて切除範囲が不適切であれ ば再発し，機能; 予後ともに不良となる，とくに，骨 内に限局した low gradeの悪性骨腫瘍の術前診断に は難渋することが多く，良性骨腫瘍と診断し掻爬する ことも稀ではなく，過少評価は厳に慎むべきである. また，骨巨細胞腫の治療では病巣掻爬骨セメント充填 術で再発もなく良好な機能が得られるが，骨外腫瘤が 認められるものはこれを確実に切除しなければ再発す るので注意を要する。また，high grade 骨腫瘍に対 する動注化学療法併用についてみると, 著効例では一 部の marginal margin が許されるかもしれないが, 無効例では的確な (curative) wide margin が必要 であり，切離断術を選択する事も多い．

切除後の再建術についてみると scapulectomy や 関節外切除が必要な例での Tikhoff-Linberg procedure などの切除術のみでも筋腱の切離端の縫着に配 慮すれば instabilityのない比較的良好な機能を維持 できる，人工骨関節置換例では，人工䩲帯を使用し筋 腱を縫着する必要があり, 切除範囲の広範な例では, 人工肩関節 ${ }^{5}$,, 人工膝関節 ${ }^{2}$ 共に連結型が機能的には 優れていた ${ }^{4)}$. 若年者や脛骨近位切除例では材質, 型 式共に解決すべき問題が残る。いずれにしろ，術後の
良好な患肢機能を温存するには早期の機能訓練が可能 な治療法を選択すべきである。

予後不良例をみると，軟骨肉腫は巨大腫瘤を有する 骨盤発生例，骨肉腫は非定型例と進行例 (stage III), Ewing 肉腫は動注化学療法が奏功しなかった肩甲骨 発生例（動注用カテーテルの位置不良？），MFH は 大腿骨発生病巣择爬例，巨細胞腫は骨外腫瘤を有する 橈骨発生例などであった。これらの治療成績を向上さ せるには，早期発見 ${ }^{3)}$, 適切な生検アプローチ, 正確 な術前診断，適切な手術適応，転移にも有効な動注化 学療法の薬片選択および的確な surgical margin な ど一貫して慎重に望めば患肢温存療法は悪性骨腫瘍の 治療法としての重要な役割を果たすものと思われる.

また，合併症に対する追加手術では，人工関節勒带 断裂例では膝再建用人工勒带の再置換が，人工関節遅 発感染例では rotation plasty が有用であった，と くに，後者は若年者の初回手術としても有利な点が多 いと思われた。

\section{ま と め}

当科で行った広範切除術を必要とした骨巨細胞腫 3 例と原発性悪性骨腫瘍 16 例に対する患肢温存療法の 機能と予後を報告した。術後患肢機能評価は excel一 lent 4 例, good 10 例, fair 2 例, poor 3 例と比 較的良好であった。予後は局巣再発 7 例 $(37 \%)$ ，遠 隔転移 9 例 $(47 \%)$, 死亡 8 例 $(42 \%)$, 無病生存 11 例 $(58 \%)$ と余りょくなかった。しかし，適切な生検 アプローチから的確な surgical margin までを，一 貫して慎重に望めば患肢温存療法は悪性骨腫瘍の有用 な治療法となる。

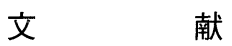

1）伊崎輝昌, 高岸直人, 葉 山泉ほか：Multicentric Osteosarcoma の治療経験. 整外と災外，38：1574-1578, 1990.

2）鈴木 斉, 高岸直人, 葉 山泉ほか: 悪性腫瘍に対す るセラミック人工膝関節置換術．整外と災外，34:471475, 1985.

3）葉 山泉, 高岸直人, 田中幹夫ほか：アトリアマイシ ンの大量間歇動注療法にて緩解している Ewing 肉腫の治 療経験. 整外と災外，30:564-567，1982.

4）葉 山泉：骨肉腫患肢温存療法の適応と手技. M B Ortho., $27: 61-72,1990$.

5）葉 山泉，高岸直人，諫山照刀ほか：上腕骨近位原発 
性悪性骨腫瘍に対する連結型人工肩関節置換術. 肩関節, $14: 26-30,1990$.

6）葉 山泉, 高岸直人, 諫山照刀ほか : 原発性悪性骨腫 瘍における長期生存例の人工膝関節置換術後の合併症に 対する膝関節再建術. 整外と災外, 40:507-511，1991.

\section{質 問州大学 岩本 幸英}

上腕骨近位例で関節内切除を行なった例では, tra- pezins 等で被覆すれば脱転しないので，人工肩関節 でなく人工骨頭で十分ではないか？

解 答福岡大学 葉 山泉

人工肩関節の連結型が三角筋機能が温存されていれ ば上肢挙上が可能で, 温存されていない例でも安定し た成績が得られると考えている。 